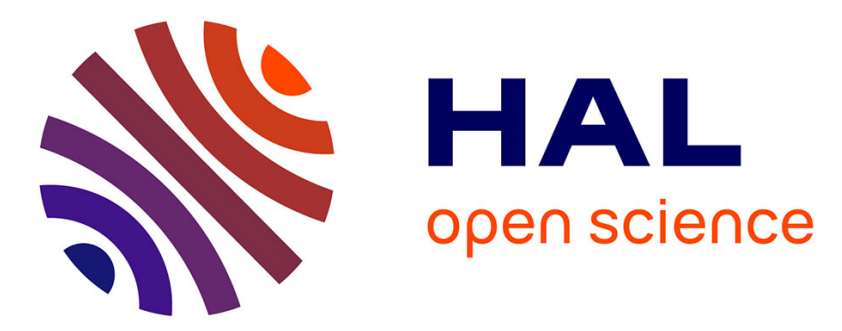

\title{
High temperature corrosion of MA 956 in sulfidizing/oxidizing/carburizing environments : a study of the influence of preoxidation on the corrosion resistance of the alloy \\ F. Uberti, F. Gesmundo, G. Toledo
}

\section{- To cite this version:}

F. Uberti, F. Gesmundo, G. Toledo. High temperature corrosion of MA 956 in sulfidizing/oxidizing/carburizing environments: a study of the influence of preoxidation on the corrosion resistance of the alloy. Journal de Physique IV Proceedings, 1993, 03 (C9), pp.C9-197-C9-204. 10.1051/.jp4:1993918 . jpa-00252355

HAL Id: jpa-00252355

https://hal.science/jpa-00252355

Submitted on 1 Jan 1993

HAL is a multi-disciplinary open access archive for the deposit and dissemination of scientific research documents, whether they are published or not. The documents may come from teaching and research institutions in France or abroad, or from public or private research centers.
L'archive ouverte pluridisciplinaire HAL, est destinée au dépôt et à la diffusion de documents scientifiques de niveau recherche, publiés ou non, émanant des établissements d'enseignement et de recherche français ou étrangers, des laboratoires publics ou privés. 


\title{
High temperature corrosion of MA 956 in sulfidizing/oxidizing/ carburizing environments: a study of the influence of preoxidation on the corrosion resistance of the alloy
}

\author{
F. Uberti $\left({ }^{1}\right)$, F. Gesmundo $\left({ }^{2}\right)$ and G.P. Toledo $\left({ }^{3}\right)$
}

( $\left.{ }^{1}\right)$ Lab. of High Temperature Corrosion, CISE SpA, V. Reggio Emilia 39, 20090 Segrate (MI), Italy

$\left({ }^{2}\right)$ Istituto di Chimica, Università di Genova, Fiera del Mare, Pad. D, 16129 Genova, Italy

$\left({ }^{3}\right)$ ENEL/DSR-CRTN, Via Monfalcone 15, 20132 Milano, Italy

\begin{abstract}
The influence of preoxidation and of the presence of $\mathrm{HCl}$ or of char deposits upon the high temperature corrosion of MA 956 in simulated coal-gasification environments has been studied at $700^{\circ} \mathrm{C}$ for periods up to $2000 \mathrm{~h}$. The corrosion of the blank material produced mixed Al-Cr sulfide-oxide scales, while preoxidation led to the development of alumina scales well adherent to the substrate which were quite protective since no sulfide formation was observed even after $1000 \mathrm{~h}$ exposure to the sulfidizing gases. On the contrary, $\mathrm{HCl}$ produced a significant enhancement of the corrosion rate of the bare alloy: however, preoxidation was able to afford a reasonable degree of protection even in this case. Coal chars had little effect on the corrosion in the absence of $\mathrm{HCl}$.
\end{abstract}

\section{Introduction.}

The atmospheres relevant for coal gasification (CG) are especially aggressive towards materials at high temperatures due to a combination of high sulfur and carbon activities with low oxygen activities [1]. In fact, high-temperature alloys have been designed to have acceptable resistance to oxygen corrosion and contain sufficient $\mathrm{Cr}$ and sometimes $\mathrm{Al}$ or a combination of both to produce protective $\mathrm{Al}_{2} \mathrm{O}_{3}$ or $\mathrm{Cr}_{2} \mathrm{O}_{3}$ scales [2]. However, they are not sufficiently resistant to corrosion by sulfur, so that the main degradation mechanism of alloys in CG atmospheres (CGA) is due to the formation of sulfide or of mixed oxide-sulfide scales [1, 3]. Acceptable corrosion rates can only be obtained by forming protective oxide scales, which in turn requires suitable combinations of $\mathrm{O}_{2}$ and $\mathrm{S}_{2}$ activities in the gas $[1,3]$.

ODS alloys are especially suited for high-temperature applications due to their very good mechanical properties and resistance to corrosion in aggressive environments [4]. In particular, MA 956 contains sufficient $\mathrm{Cr}$ and $\mathrm{Al}$ to form, upon exposure to $\mathrm{O}_{2}$ atmoshperes, $\mathrm{Al}_{2} \mathrm{O}_{3}$ scales particularly protective due to their good adherence produced by the dispersion of yttria particles in the alloy [4]. The protectiveness of alumina and chromia scales can also be increased by the addition of reactive elements directly to the alloy [5].

Recently chlorine compounds and coal fines deposited on the alloy surface have been found to accelerate the corrosion of metallic materials in CGA [6-8]. On the contrary, their corrosion resistance may be significantly improved if they are preoxidized before being exposed to CGA [1,3]. The aim of the present study is to examine the effect of preoxidation 
and of the presence of $\mathrm{HCl}$ and of coal-char deposits on the corrosion behavior of MA 956 in CGA at $700^{\circ} \mathrm{C}$. Some aspects of the corrosion behavior of the same alloy in CGA have already been reported previously [9-11].

\section{Experimental.}

The MA 956 specimens having the composition (wt. \%) $20 \mathrm{Cr}, 4.5 \mathrm{Al}, 0.5 \mathrm{Ti}, 0.5 \mathrm{Y}_{2} \mathrm{O}_{3}$ were cut from a bar in the form of small discs of $10 \mathrm{~mm}$ diameter, $4 \mathrm{~mm}$ thick, ground through 180-grit SiC paper, degreased and dried before use. All corrosion tests were carried out at $700^{\circ} \mathrm{C}$, while preoxidation was obtained by exposing the samples to air at $1000{ }^{\circ} \mathrm{C}$ for $20 \mathrm{~h}$, yielding $\mathrm{Al}_{2} \mathrm{O}_{3}$ scales 2-4 microns thick [12]. The corrosion tests in CGA without $\mathrm{HCl}$ have been performed in a vertical, top-loaded autoclave equipped with a three-zone furnace described elsewhere [11]. For the char tests the coupons have been accommodated in single alumina crucibles and immersed in the chars. Two different types of chars supplied by Coal Research Establishment (Orchard, UK) and produced in two different runs, in one of which limestone additions were used to eliminate $\mathrm{H}_{2} \mathrm{~S}$ from the syngas, were used. They contained (wt. \%) $72.1 \mathrm{C}$ and $1.53 \mathrm{~S}$ (char $\sharp$. 1) and $68.2 \mathrm{C}$ and $1.24 \mathrm{~S}$ (char $\sharp$. 2) plus other common inorganic impurities $\left(\mathrm{SiO}_{2}, \mathrm{Al}_{2} \mathrm{O}_{3}, \mathrm{Fe}_{2} \mathrm{O}_{3}\right.$ etc.). In particular, the $\mathrm{Ca}$ content was 2.2 for char $\sharp$. 1 and 16.8 for char $\sharp$. 2, respectively. After each test interruption, new chars were used. The duration of tests was $1000 \mathrm{~h}$ without chars and $2000 \mathrm{~h}$ with chars, with discontinuous weight-change measurements after convenient time intervals. The initial gas composition (vol. \%) was $7 \mathrm{CO}, 1.5 \mathrm{H}_{2} \mathrm{O}, 0.4 \mathrm{H}_{2} \mathrm{~S}$, balance $\mathrm{H}_{2}$ : the equilibrium activities of $\mathrm{O}_{2}, \mathrm{~S}_{2}$ and $\mathrm{C}$ at $700^{\circ} \mathrm{C}$ were $6.6 \times 10^{-24} \mathrm{~atm}, 7.0 \times 10^{-10}$ atm and 0.36 , respectively.

The tests with $\mathrm{HCl}$ were carried out only for $200 \mathrm{~h}$ without chars using the same procedure in a horizontal tube with a five-zone furnace. The gas was the same as in the previous tests, but contained also $0.5 \mathrm{vol} . \% \mathrm{HCl}$. The equilibrium activity of $\mathrm{Cl}_{2}$ was $7.5 \times 10^{-16} \mathrm{~atm}$, while those of $\mathrm{O}, \mathrm{S}$ and $\mathrm{C}$ were the same as before. Corroded samples have been examined by means of XRD, OM, SEM and EMPA to determine the scales morphology and composition.

\section{Results.}

The weight-gain data for bare samples corroded in CGA up to $1000 \mathrm{~h}$ are shown in figure 1: no measurable weight gain was detected for the preoxidized samples. The results for samples corroded with coal chars up to $2000 \mathrm{~h}$ are shown in figure 2. Finally, figure 3 shows the kinetics results for the corrosion of the bare and preoxidized alloy in CGA with $\mathrm{HCl}$ up to $200 \mathrm{~h}$. According to these results proxidation is extremely effective in reducing subsequent attack by this atmosphere. The presence of chars has only a reduced beneficial effect on the corrosion behavior of the bare alloy, yielding a moderate rate decrease, especially for char $\sharp$.1. On the contrary, a small enhancement of the corrosion rate is observed for preoxidized samples. Finally, $\mathrm{HCl}$ addition produces a strong corrosion enhancement: even in this case preoxidation is beneficial, reducing the corrosion rate quite significantly, but not as effectively as for exposure to $\mathrm{HCl}$-free gases. In fact, the corrosion rate of preoxidized samples exposed to the HCl-containing mixture is similar to that of the bare alloy in the base CGA.

The structure of the scales formed on bare samples in the base CGA is shown in figure 4: the outer scale contains an inner layer rich in $\mathrm{Al}$ in combination with $\mathrm{O}$ and $\mathrm{S}$ and an outer chromia layer. However, a 20-microns-thick region of internal attack also forms, presenting a combination of oxidation and sulfidation of $\mathrm{Al}, \mathrm{Cr}$ and $\mathrm{Ti}$, which contribution significantly to 


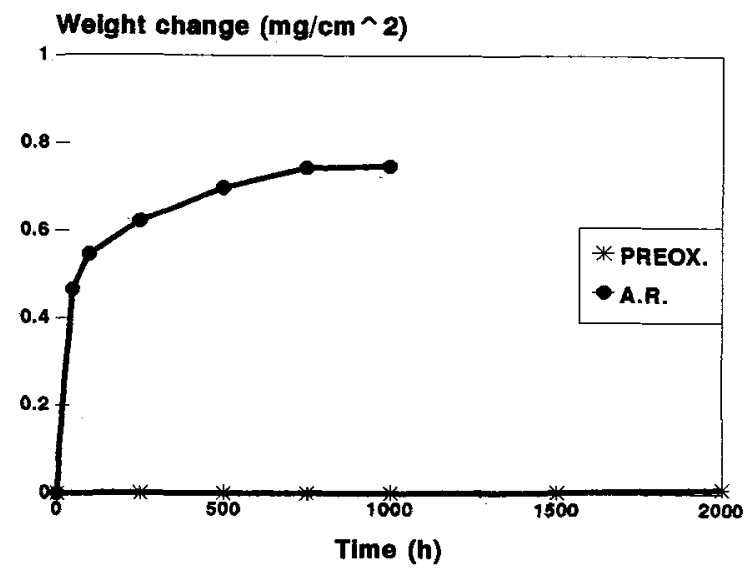

Fig. 1. - Kinetics of corrosion of MA 956 in the CGA at $700^{\circ} \mathrm{C}$.

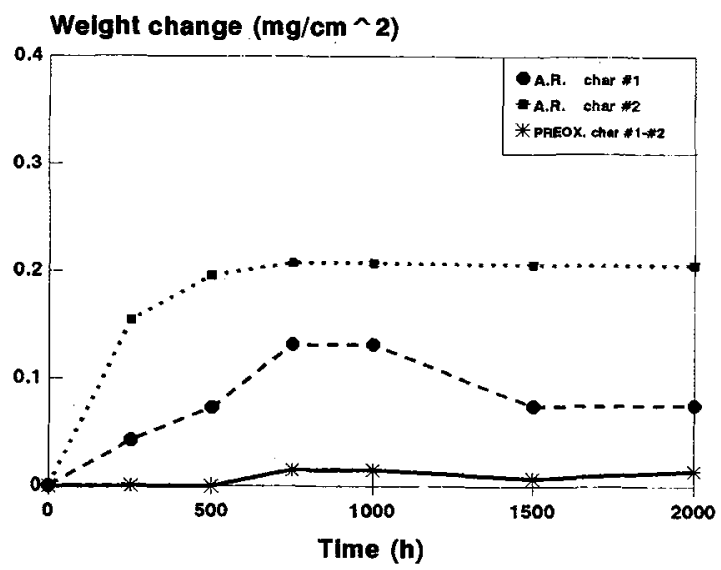

Fig. 2. - Kinetics of corrosion of MA 956 in the CGA with char deposits at $700^{\circ} \mathrm{C}$.

the overall metal loss [3]. Preoxidized samples with or without chars show only a continuous adherent alumina layer without traces of sulfur, in agreement with kinetic data. The scale formed on bare samples corroded with chars (Fig. 5) contains an inner alumina and an outer chromia layer with small S-rich islands and no internal attack. Thus, the corrosion resistance in the presence of chars is improved because the scale becomes impervious to both $\mathrm{O}$ and $\mathrm{S}$ penetration.

The corrosion of the bare alloy in CGA with $\mathrm{HCl}$ (Fig. 6) produces thick (110 microns) external scales with an inner layer of mixed chromia and alumina and a thicker outer region of chromium sulfide. At some places the outer layer contains instead an iron-rich oxide, probably an Fe-Cr spinel. In addition, a deep zone (200 microns) of internal sulfidation involving mostly $\mathrm{Cr}$ is also observed, leading to a heavy overall metal loss. Preoxidized samples have much thinner scales of complex structure (Fig. 7). The initial alumina layer (external) is broken at some places and in any case has lost its protective properties, allowing penetration of 


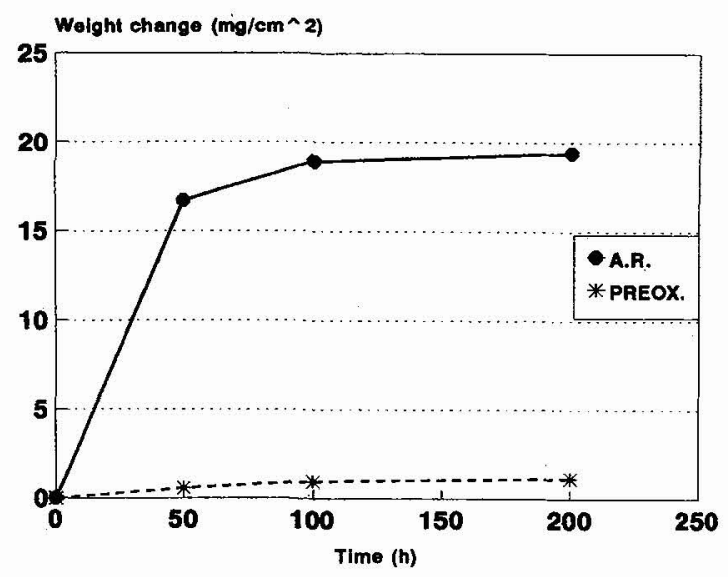

Fig. 3. - Kinetics of corrosion of MA 956 in HCl-containing CGA at $700^{\circ} \mathrm{C}$.

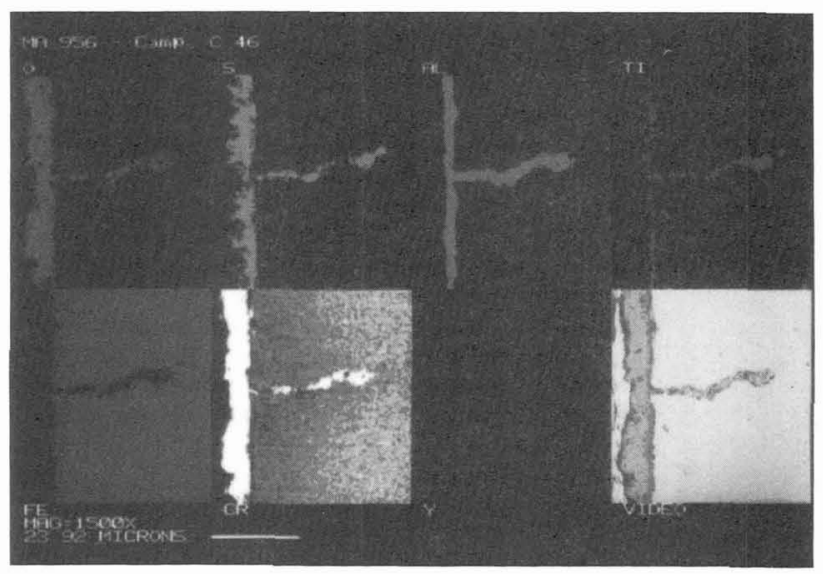

Fig. 4. - SEM micrograph and X-ray maps of a cross section of MA 956 corroded in the CGA for $1000 \mathrm{~h}$ at $700^{\circ} \mathrm{C}$.

both $\mathrm{O}$ and $\mathrm{S}$ to form a chromia layer with some $\mathrm{Cr}$ sulfide at the base of the scale. The scale has also grown out of the performed oxide layer forming especially $\mathrm{Cr}$ sulfide with some iron. Moreover, a heavy internal oxidation of $\mathrm{Al}$ (without sulfidation) has also developed inside the alloy, even though the depth of internal attack (6 microns) is much smaller than that on the bare alloy. In any case, preoxidation is not able to prevent attack in this mixture, even if it helps to reduce the corrosion rate significantly with respect to the bare alloy.

\section{Discussion.}

The gas composition in terms of the equilibrium $P\left(\mathrm{O}_{2}\right)$ and $P\left(\mathrm{~S}_{2}\right)$ is shown in the superimposed phase-stability diagram for the three $\mathrm{M}-\mathrm{O}-\mathrm{S}$ systems at $700^{\circ} \mathrm{G}$ in figure 8 . The stable phases (for the pure metals) are $\mathrm{Cr}_{2} \mathrm{O}_{3}, \mathrm{Al}_{2} \mathrm{O}_{3}$ and $\mathrm{FeS}$. In purely oxidizing atmospheres the 


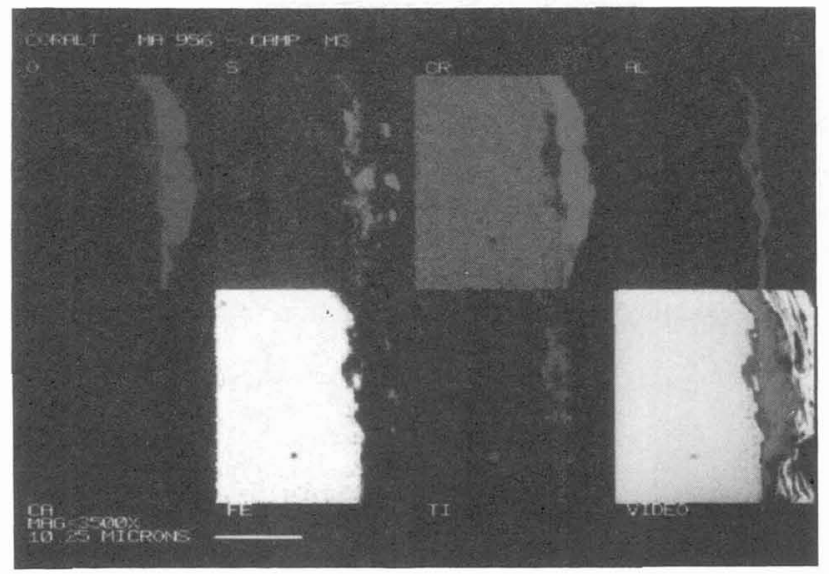

Fig. 5. - SEM micrograph and X-ray maps of a cross section of MA 956 corroded in the CGA for $2000 \mathrm{~h}$ at $700^{\circ} \mathrm{C}$ with char deposits (char N. 2).

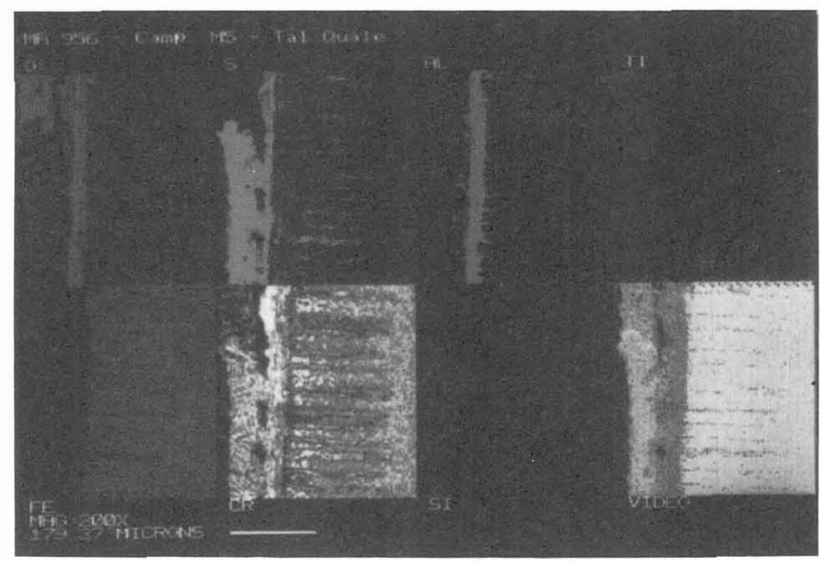

Fig. 6. - SEM micrograph and X-ray maps of a cross section of preoxidized MA 956 corroded in the CGA with $\mathrm{HCl}$ for $200 \mathrm{~h}$ at $700^{\circ} \mathrm{C}$.

$\mathrm{Al}$ content of this alloy is sufficient to form alumina scales, due to the synergistic effect of $\mathrm{Cr}$ and $\mathrm{Al}$ [4]. However, corrosion in CGA may produce mixed oxide-sulfide or even purely sulfide scales $[1,3]$. For chromia formers the growth of oxide scales requires gas compositions falling in the field of $\mathrm{Cr}_{2} \mathrm{O}_{3}$ stability but sufficiently far from the $\mathrm{Cr}_{2} \mathrm{O}_{3}-\mathrm{CrS}_{x}$ equilibrium and more precisely to the right of a line known as the kinetic boundary (k.b.) [3]. The location of this k.b., which is parallel to the $\mathrm{Cr}_{2} \mathrm{O}_{3}-\mathrm{CrS}_{x}$ thermodynamic boundary, depends on both the alloy composition and temperature and has been approximately defined for two chromia formers, i.e. alloy 800 and 310 stainless steel and for the alumina former Fecralloy (which has a composition very similar to MA 956, but contains $\mathrm{Y}$ rather than $\mathrm{Y}_{2} \mathrm{O}_{3}$ ) [3], but not yet for 


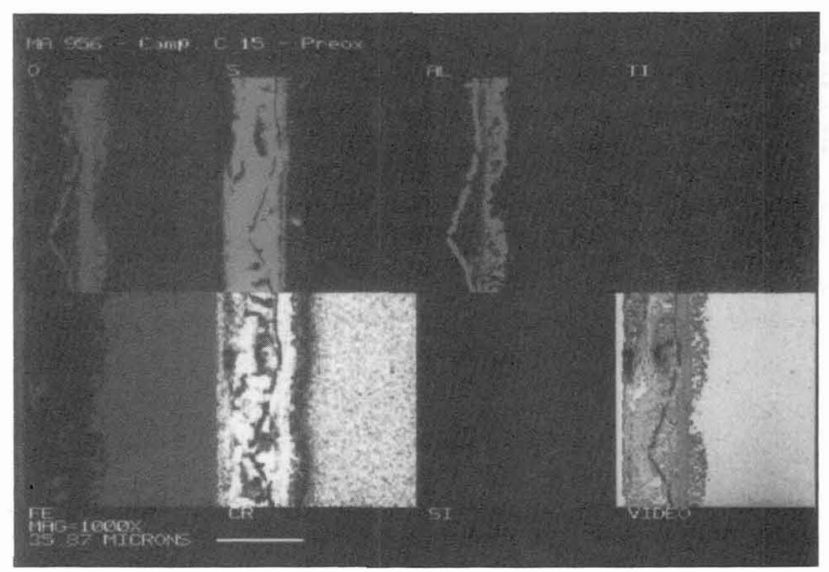

Fig. 7. - SEM micrograph and X-ray maps of a cross section of preoxidized MA 956 corroded in the CGA with $\mathrm{HCl}$ for $200 \mathrm{~h}$ at $700^{\circ} \mathrm{C}$.

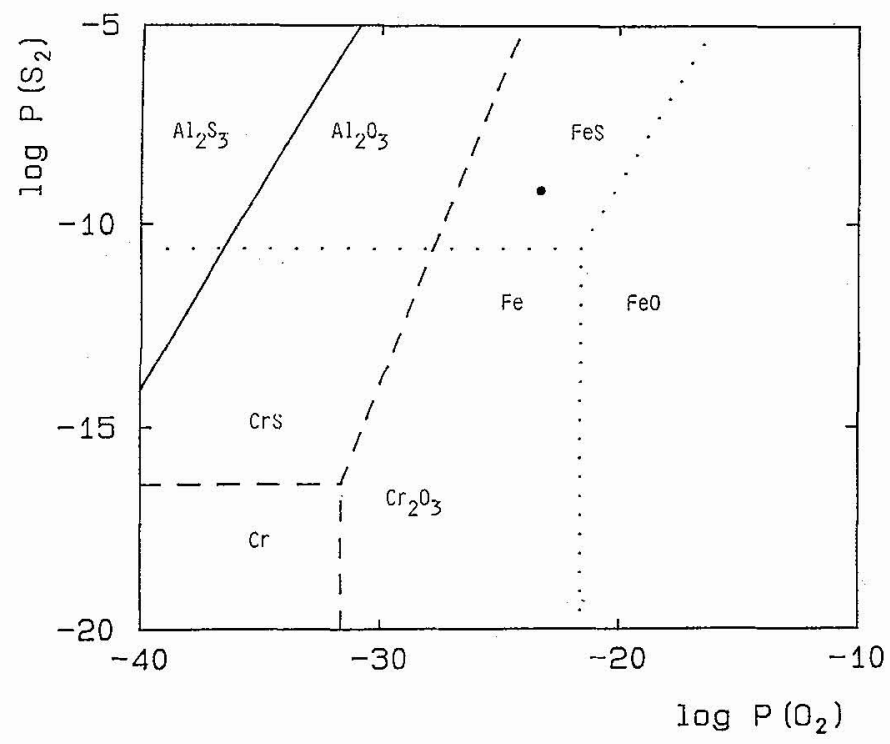

Fig. 8. - Superimposed phase stability diagrams for the Al-O-S (solid line), Cr-O-S (dashed lines) and Fc-O-S (dotted lines) systems at $700{ }^{\circ} \mathrm{C}$ : the dot represents the equilibrium composition of the gas mixture used.

MA 956, even if some corrosion studies in CGA have already been carried out for this alloy [9-11].

According to the available results, the k.b. location for Fecralloy at $700^{\circ} \mathrm{C}$ is approximately the same as for chromia formers [3], in spite of the different nature of the oxides growing under oxidizing conditions [4]. The equilibrium composition of the present gas mixture falls to the left of k.b. for Fecralloy, because its oxygen excess parameter is only $1.35 \times 10^{3}$, while 
the corresponding critical value used to define the k.b. is $10^{7}$ [3], in agreement with the observed formation of mixed sulfide-oxide scales. However, parabolic extrapolation of the thickness of metal consumed including the depth of internal attack leads to an overall metal consumption rate of $8.3 \times 10^{-2} \mathrm{~mm} /$ year [3], which in any case is significantly smaller than the maximum acceptable limit of around $0.5 \mathrm{~mm} /$ year [3]. Thus, the formation of mixed scales at the rate observed in this mixture can still be tolerated.

Sample preoxidation carried out in air at $1000^{\circ} \mathrm{C}$ for $20 \mathrm{~h}$ produced $\mathrm{Al}_{2} \mathrm{O}_{3}$ scales which prevent completely the formation of sulfides in the present atmosphere up to the maximum corrosion time tested $(1000 \mathrm{~h})$. Thus, they act as very effective barriers not only against the penetration of sulfur, but also against the outward diffusion of iron [13], which would form FeS on the outer scale surface, leading very likely to breakaway corrosion $[1,3]$.

The presence of $\mathrm{HCl}$ in the gas $(0.5 \mathrm{vol}$. \%) is strongly detrimental, producing a large increase of the corrosion rate as well as important changes in the scales morphology and composition. A few studies of the corrosion of Fecralloys in coal gasification atmospheres in the presence of $\mathrm{HCl}$ carried out at $450^{\circ} \mathrm{C}$ have shown that $\mathrm{HCl}$ leads to significant increases of the corrosion rate when mixed oxide-sulfide scales form [6-8]. A recent study by Gohil $e t$ al. [8] confirmed the negative influence of $\mathrm{HCl}$ on the corrosion resistance of Fecralloys and showed that a major effect was related to the kind of surface finish.

The present results are in substantial agreement with those reported above concerning the behavior of the Fecralloy steels, whose composition is very similar to that of MA 956. In particular, $\mathrm{HCl}$ produces a substantial increase of the amount of sulfides in the scale as well as an important internal sulfidation, probably as a result of the growth of porous scales due to the formation of volatile iron chlorides [8]. Moreover, preoxidation is not effective in protecting against corrosion in this mixture because the initial oxide layer becomes broken and porous after exposure to $\mathrm{HCl}$, allowing oxidation and sulfidation to take place both beneath and above it.

The effect of coal chars on the corrosion of alloys in CG atmospheres has been studied a number of times [6, 14-17]. According to Perkins [18] the two most important factors are the content of sulfur and the form in which $S$ is present in the char. In fact, sulfur of volatile organic compounds is very aggressive because it rises the sulfur pressure at the alloy surface. On the contrary, pyritic sulfur has little effect on the corrosion rate [189]. Spent char, which is the kind present in gasifiers, contains less than $0.6 \% \mathrm{~S}$, most of also chars containing an excess of free $\mathrm{CaO}$ produce little sulfidation because the local $P\left(\mathrm{~S}_{2}\right)$ is fixed by the $\mathrm{CaO} / \mathrm{CaS}$ equilibrium to quite low levels [17]. The high corrosion rates noted in the presence of some chars [14-16] are due to their high volatile sulfur content [18]. In fact, exposure to low-sulfur chars has only little effect on the corrosion rate [16]. The results obtained in the present study are in agreement with the moderate sulfur content of the chars used and indicate that it must be mostly present as inorganic compounds (sulfides and/or sulfates).

\section{Conclusions.}

The results obtained in the present study allow the following conclusions to be drawn.

- The presence of 0.5 vol. $\% \mathrm{H}_{2} \mathrm{~S}$ in a gas mixture with $6.6 \times 10^{-24}$ atm $\mathrm{O}_{2}$ leads to the formation of mixed scales containing $\mathrm{Al}$ and $\mathrm{Cr}$ with internal attack. However, the overall rate of metal loss is still acceptable for practical application under these conditions.

- The presence of $\mathrm{HCl}$ produces a large increase of the corrosion rate of the bare alloy. 
- Air preoxidation produces alumina scales which prevent sulfidation attack in $\mathrm{HCl}$-free CG atmospheres up to at least $1000 \mathrm{~h}$.

- Preoxidation affords some protection against corrosion in CGA even in the presence of $\mathrm{HCl}$ in the gas, but is much less effective than in $\mathrm{HCl}-$ free gases.

- The presence of low-sulfur char deposits has a slight beneficial effect on the corrosion behavior of the as-received but not of the preoxidized MA 956 samples.

\section{References}

[1] GRABKe H.J., NORTON J.F., CASTEels F.G., High Temperature Alloys for Gas Turbines and Other Applications 1986, Vol. I, W. Betz Ed. (Reidel Pub. Co., Dordrecht, 1986) p. 245.

[2] KOFSTAD P., High Temperature Corrosion (Elsevier Applied Sci., London, 1988).

[3] Gesmundo F., High Temperature Materials for Power Engineering 1990, Vol. I (Kluwer Acad. Pub. Dordrecht, 1990) p. 67.

[4] QUADDAKERS W.J., Werkst. Korros. 41 (1990) 659.

[5] STRINGER J., Mater. Sci. Eng. A120 (1989) 129.

[6] SAUNDERs S.R.J., SChlieber S., J. Mater. Energ. Syst. 7 (1986) 353.

[7] COLEY K.S., BLICH K., RHOADES-BROWN J.E., Werkst. Korros. 40 (1989) 175.

[8] Gohil D.D., SAUnders S.R.J., BENNETT M.J., High Temperature Materials for Power Engineering 1990, E. Bachelet Ed. (Kluwer Academic Publishers, Dordrecht, 1990) p. 189.

[9] SANTORELli R.L., Norton J.F., BRegani F., Werdst. Korros. 41 (1990) 669.

[10] SANTORElli R.L., NORTON J.F., BREgani F., Proc. 11th International Corrosion Congress, Vol. IV (Associazione Italiana di Metallurgica, Milano, 1990) p.1.

[11] SANTORELli R.L., BREGANI F., NORTON J.F., Metall. Ital. 83 (1991) 1113.

[12] UberTi F., SANTORElli R., BREGANi F., EUROCORR/91, I. Karl, Bod M. Eds., Vol. 1 (Budapest, 21-25 Oct., 1991).

[13] Sheybany S., Douglass D.L., Oxid. Met. 29 (1988) 307.

[14] Sheybany S., Douglass D.L., Oxid. Met. 30 (1988) 433.

[15] DOUglass D.L., BHIDE V.S., VINEBERG E., Oxid. Met. 16 (1981) 29.

[16] TIEARNEY T.G., NATESAN K., Oxid. Met. 17 (1982) 1.

[17] Foerster T.F.W., Levy A.V., NEWMAN J.S., High Temperature Corrosion, R. Rapp Ed. (NACE, Houston, 1983) p. 354.

[18] PERkins R.A., High Temperature Corrosion, R. Rapp Ed. (NACE, Houston, 1983) p. 345. 